\title{
Skin Basal Cell Carcinoma with Adnexal Differentiation
}

National Cancer Institute

\section{Source}

National Cancer Institute. Skin Basal Cell Carcinoma with Adnexal Differentiation. NCI

Thesaurus. Code C38109.

A basal cell carcinoma of the skin that is characterized by adnexal differentiation. 